\title{
V.N. Chepik
}

\section{A QUIET REVOLUTION OF EDWARD HEATH}

The article is covering the initial period of the advancement of neo-conservatism in Britain. The author claims that the rise of neo-conservative ideology was the result of the influence of domestic factors such as economic instability and ineffective Labour government policy as well as international ones, which decreased the British influence across the world. The author emphasizes radical changes in organization of government and industrial structures as well as changes in the mode of life of the British people. The author suggests that these revolutionary reforms carried out on a large-scale touched upon, practically, each aspect of a daily life in British society. They laid the foundation for the further neo-conservative transformations inside of the country and strengthened positions of the Great Britain on a world stage. Refs 28.

Keywords: A Quiet Revolution, neo-conservatism, reforms, individualism, freedom and responsibility.

For citation: Chepik V.N. A Quiet Revolution of Edward Heath. Vestnik of Saint Petersburg University. History, 2017, vol. 62, issue 4, pp. 855-864. https://doi.org/10.21638/11701/spbu02.2017.412

\section{B. H. Чепик}

\section{ТИХАЯ РЕВОЛЮЦИЯ ЭДВАРДА ХИТА}

В статье рассматривается начальный этап становления британского неоконсерватизма. Автор утверждает, что укреплению влияния неоконсерваторов способствовали не только внутренние причины, такие как нестабильность экономической ситуации и неэффективная политика лейбористского правительства, но и внешние факторы, снижавшие конкурентоспособность британских товаров и оказывавшие влияние на ослабление роли Великобритании в мире. В статье сделан акцент на радикальной природе внутриполитических и социально-экономических преобразований, затрагивавших не только организацию органов государственного управления, отраслей промышленности, но и стиль жизни британцев. Автор утверждает, что осуществлявшиеся реформы, по своей сути революционные, носили широкомасштабный характер, затронувший практически каждый аспект повседневной жизни британского общества, заложили фундамент для дальнейших неоконсервативных преобразований внутри страны и усиления позиций Великобритании на мировой арене. Библиогр. 28 назв.

Ключевые слова: Тихая револющия, неоконсерватизм, реформы, индивидуализм, свобода и ответственность.

After the Second World War conservative ideology has proved to be under the influence of ideas of social reformism. The reformist doctrine dominated the Conservative party down to the middle of 1960. Its ideologists such as H. Macmillan, R. Butler, R. Boothby, etc. were opposed both the Liberals with their extreme ideas of free market and unchecked competition, as well as Labour's aspiration to nationalize all means of production, distribution and an exchange. They considered promotion of the socially-focused capitalism in which social justice would organically combine with economic efficiency to be their main task. However, as from the second half of 1960s under the influence of economic instability, the

Chepik Victor Nikolaevich - PhD in History, Senior Lecturer, Belorussian State Agricultural Academy, 11, Temiryazev ul., Gorky, Mogilev region, 213407, Belarus; victor_chepik@mail.ru

Чепик Виктор Николаевич - кандидат исторических наук, старший преподаватель, Белорусская государственная сельскохозяйственная академия, Республика Беларусь, 213407, Могилевский район, Горки, ул. Темирязева, 11; victor_chepik@mail.ru

(c) Санкт-Петербургский государственный университет, 2017 
devaluation of pound and decreasing of Great Britain world role, the influence of supporters of traditionally conservative values, buried in during 'the interparty consensus' was increasing in the Party. The representatives of big business within the framework of organizations based on the protection of conservatives interests, such as the 'Economic league' (1919), 'the Purposes of the industry' (1942), as well as the large research centers were engaged in the development of various aspects of conservative policy. The special role in the evolution of conservative ideology belonged to inner-party group called 'One nation' and one of its leaders, E. Heath, who went on to become the British Prime Minister in 1970.

Russian researchers such as A. Gromyko, K. Hudoley, N. Stepanova, and others have examined the activity of E. Heath as British Prime Minister. Nevertheless, some aspects of the rise of neo-conservatism in the Great Britain still require further study and interpretation. Owing to access to the documents from the British government archives as well as papers of the Conservative party conferences, it is possible now to conduct a more detailed analysis of the purposes, problems of the first stage of "a quiet revolution" that Heath proclaimed.

In 1950 nine newly-elected from the Conservative party 'backbenchers' have formed the group in Parliament called 'One nation'. Among them were E. Heath, I. Makleod, A. Mod and E. Pauel who declared that poverty had remained in the past and the Great Britain had turned to the country of "one nation". In numerous publications they supported the traditionally conservative approach to social policy which should provide not only the minimum standards for a life, but the opportunity for citizens to rise above them, as high as 'the economy, their diligence, abilities and genius' would allow them [One Nation Conservatism and social policy, 1951-64]. Becoming the leader of the Conservative party in 1965 E. Heath had called to change the mood of people all over the country, having emphasized self-reliance and hard work, thrift and individual independence. The party conference in 1968 became decisive for a course of modern conservatism. Under the slogan 'Make Life Better' the Conservatives had proclaimed a course of radical changes which should embrace each aspect of a daily life of the British people. 'That we plan, is not patching measures. We plan fundamental and branch reforms... Our work on it has already begun. The men and women will be ready, when the time comes', declared E. Heath [Edward Heath, 1968]. In his opinion, time had already come to change the way of life of British as 'the era not only in British, but also in a world history came to an end'. Britain to its honor still in the end of 1950s could admit the fact of appearance of the new world and had joined in the world processes which were directed to the foundation of the basis for modern industrial society. The new world demanded from the British, the improvement of professional skills, competitiveness, and also international integration with other countries on the basis of specialization and division of labour.

These changes which were radical by their nature Heath named 'a quiet revolution'. The revolution was needed by the conservatives to destroy much of what the Labour party had built up. The conservatives severely criticized the Labour tax policy which had, according to their opinion, but one objective: 'to tax wealth.' 'We have lowered the taxation on 450 million. In three years the Labour Government has increased taxes gathering up to 1 billion. During the Conservatives in office, foreign trade deficiency has made up 42 million. For three years of Labour rule, deficiency has grown up to 342 million. For our last three years in office, manufacture has increased by 14 percent. For their three years, we had stagnation' [Edward Heath, 1967]. The Conservatives accused the Labour 
Government not only of incompetence, but also of the immorality of the Government's actions towards the individual, the encroachment upon his liberty, the demands upon his income and property.

The new political programme which was approved at the conference in 1968 had been proclaimed the new conservative ideology to free the individual and to free economy from the Government interference. In particular, Conservatives took obligations: 'To restore respect for government, its morality and its competence; to remove the shackles of government from industry; to banish the regulation and control of business activities; to withdraw the Government from holdings in private firms and to begin to reintroduce private ownership into nationalized industries; ... to puncture the swollen corpus of bureaucracy, cut free the octopus-like grip of overcentralization; to purge the body politic of the toxins of waste, extravagance and procrastination' [Edward Heath, 1968]. According to the conservatives' leader, in order to stop overwhealming processes of stagnation in the economy and the further decreasing of Great Britain's world role, urgent measures and efforts not only by the governments, but also by the whole nation had to be taken.

The Conservatives victory in parliamentary elections in June, 1970 had proved to be the opportunity to realize in practice the idea of " a quiet revolution" which promised to British society both freedom and responsibility. 'The single and most important service that I believe this Government can do for British people is to restore to them more and more freedom, said E. Heath [Edward Heath, 1970]. The free society, from the conservatives point of view, should also be a responsible society. Their arguments were reduced to the following: if citizens should be free to make their own decisions freely they should be responsible also for their mistakes; if they should have an opportunity to enjoy freely the rewards of enterprise, they should be responsible for making sure that those rewards are justly and fairly earned; if citizens should create freely for themselves and their families that better tomorrow, they should be responsible (financially) for those who, through no fault of their own, cannot create it for themselves [Edward Heath, 1970]. For the purpose of constructing a free and responsible society, according to E. Heath, the British should have to embark on 'a change so radical, a revolution so quiet and yet so total', that it would go far beyond that decade and way the 1980s, for it was the task of building something of style with new substance and quality. 'We can hope only to begin now what future Conservative Governments will continue and complete. We are laying the foundations, but they are the foundations for a generation', Heath proclaimed [Edward Heath, 1970].

As the first step the Government had decided 'to free itself'; i.e. to free itself from excessive duties and constraining limitations which prevented the declared policy, thus, creating room for manoeuvre. In the economic sphere such limitations were the high level of public expenditure which absorbed great sums from the budget, while stimulating increasing taxation. For example, under the previous Administration public expenditure had risen from 43 per cent to 51 per cent of the gross national product and their future programme would have involved an increase in the then existed level of taxation by more than $£ 300$ million in 1974 [Public Expenditure. CONCLUSIONS of the Cabinet, 14 September, 1970].

The high level of State expenditure prevented lowering taxation and did not allow stimulating business. Regarding this, the Government had declared revision of the State expenditure according to the new conservative course. There planned reduction in public expenditure of $£ 1,700$ million in $1974-75$, having begun with several hundred million in 
1971/72 [THE ECONOMIC OUTLOOK. Memorandum by the Prime Minister. 9 September 1970]. In particular, it was planned:

1. To cancel the governmental investment grants for the industry (a total sum $£ 700$ million). Instead, it was offered to find out the most effective alternative ways to restore financing and to promote investment in the future by means of taxes reduction for individuals as well as by changes of the taxation of the companies.

2. To reduce the government financing of scientific research as they did not bring quick economic feedback. In the further, it was planned to shift their financing on the industry, universities and a private sector.

3. To lower by 5-10 per cent financing of the nationalized industry in 1972/73; put the expenditure ceiling to the level of $£ 1.5$ billion [THE ECONOMIC OUTLOOK. Memorandum by the Prime Minister. 21 July 1970].

Expenditure revision in most degree was directed against the social sphere. The Minister of Social Welfare was offered the essential reduction of expenditures in the social sphere and public health services. In particular, on health and welfare services he had agreed to savings amounting to some $\mathfrak{E} 60$ million in $1971-72$, subject to certain exemptions and offsetting expenditures to protect those in need. [Public Expenditure. CONCLUSIONS of the Cabinet, 15 September, 1970]. Also the decision was taken:

1. To cancel free-of-charge school dinners. Thus, it was expected the economy of $£ 24$ million in 1971/72, and of $£ 40$ million in $1974 / 75$.

2. To cancel free-of-charge school milk since September, 1971 at primary and special schools. The economy should earn in 1971/72 $£ 9$ million and $£ 14$ million in 1974/75. However, during discussions in the Government it was agreed to preserve free-of-charge milk in kindergartens and houses of babies, as well as in some medical cases. It had reduced savings up to $£ 6$ and $£ 9$ million a year correspondingly.

3. To cancel sale of Welfare (cheap) milk that saved $£ 30.5$ million (except for needy and large families).

4. To limit uprating of social benefits in 1971 and 1973 by no more than living standard [PUBLIC EXPENDITURE. Memorandum by the Chief Secretary, Treasury. 10 September 1970].

Other factor which put limitations on the objectives of new policy was the high rate of inflation (15\%). It pushed up growth of consumer prices in the home market and influenced negatively on the competitiveness of the British goods in foreign markets. The government recognized that the main reason for inflation was excessive demand for wage increases from the Trade Unions. Accusing Labour of unreasonable wage increase before parliamentary elections, the Minister of Finance declared that in June, 1970 that wages were running at a level of 12 per cent higher than the year earlier; wage rates in July were running a 10 per cent higher; and wage settlements in that month had yielded average increases of 14 per cent. However, prices had in fact risen by only 6.5 per cent over the past year, the economy had been growing only by some $2-3$ per cent a year. Furthermore, there was a $£ 53$ million surplus on the balance of payments in the second quarter of the year, compared with $£ 150$ million in the first quarter [Economic Affairs. CONCLUSIONS of the Cabinet, 3 September, 1970].

Great economic damage was done by strikes. Except for losses from broken contracts, the industry suffered greater industrial losses. For example, due mainly to an increase in the number of strikes, the figure of working days lost in 1969 had appeared the highest 
since 1957 when there was a loss of over 8.4 million working days and had made just over 6.8 million. However, the quantity of strikes and their participants continued to grow, that became a menacing problem practically for all basic branches of economy. The total number of the working days lost within first 5 months of 1970, nearly 4 million, was the highest for the comparable period of any year since 1962, and was almost double the figure for the corresponding period of 1969 [INDUSTRIAL RELATIONS SITUATION. Memorandum by the Secretary of State for Employment and Productivity. 1 July 1970]. Nevertheless, the existing system of industrial relations prevented the government to undertake effectual measures. Under the existing law (laws on trade unions of 1871 and 1906) Trade Unions actually enjoy immunity from legal action. Regarding to this, legal decision of the problem was required. In July 1970 discussion of the Industrial relations Bill (becoming law in August 1971) had begun. Created for the termination of strikes and resolutions of disputes, the new system of industrial courts transferred the contract into the category of legally binding documents and provided alongside with other innovations and interdictions the legal responsibility of workers and employers alike for its default (brought into effect only since February, 1972) [INDUSTRIAL RELATIONS LEGISLATIN. Memorandum by the Secretary of State for Employment and Productivity. 28 July 1970].

Despite the struggle against inflation and unreasonable wage increases, the Conservatives, nevertheless, adhered to policy of income growth for the population. They did not refuse the Labour program to increase wages in three annual stages and went on with its implementation. The last stage of these would have been brought into effect from April, 1971; but under the circumstances the Government decided it sensible to implement this increase also from 1 January, 1971.

The Conservatives gave great value to protection of a principle of an economic inequality. They argued that owing to distinctions in intellectual or physical abilities, social circumstances some citizens in a society should have more than others. It speaks for the decision of the Government to raise wages to high-ranking officials. Furthermore, it had been endorsed the increase since 1 July, 1970 for Under Secretaries being calculated at 8,5 per cent rather than 6,2 per cent, having established a ceiling of salaries growth for the civil servants (up to and including Assistant Secretaries) to $£ 14,000$. [Pay of the Higher Civil Service. CONCLUSIONS of the Cabinet, 21 July, 1970]. With the purpose of gaining a broad support of the Government policy the Prime Minister had declared that "wages and salaries are forecast to rise by 11 per cent this year, and nearly as much again next year". Thus, the retail price index was forecast to rise by 6.5 per cent in 1970 and nearly by 5.5 per cent in the following year [THE ECONOMIC OUTLOOK. Memorandum by the Prime Minister. 21 July 1970].

For the first weeks of the Conservative Government in office freedom was restored to local authorities to decide their own form of education with "no more compulsory comprehensives". Therefore parents and schoolboys got the right of a free choice of an elementary education form (private or municipal) sources. This opened the opportunities for governmental grants reduction. Particularly, it was planned to reduce educational expenditure by $£ 180$ million over the four years from 1971-72 to 1974-75. [Public Expenditure. Education. CONCLUSIONS of the Cabinet, 5 October, 1970].

In order to pursue 'the proprietor's democracy' policy the Conservatives had restored freedom to local councils to sell council houses, and to tenants freedom to buy them. The Land Commission was abolished, the new offer was made on the higher "fair rent" which, due to the increase, should reduce a difference between purchasing and renting a house, 
as well as to stimulate owners to improve the quality of their houses for rent. In particular, the decision was taken on an annual increase of rent in the public sector by 10 up to 15 cents. The Government's strategy had been carefully designed to protect the poorest segments of the community. But it was pointed out that their measures would bear hardly on families with incomes of $£ 25$ or $£ 30$ a week. [Housing Finance. CONCLUSIONS of the Cabinet, 30 October, 1970]. The new housing policy, on the one hand, provided direct help by means of indemnifications of rent cost, but on the other provided an opportunity to pay higher rent, owing to reduction of taxes and growth of incomes of citizens in the future. According to the Minister of an Environment, the housing policy should become 'rational, fair and charitable' [THE REFORM OF HOUSING FINANCE. Memorandum by the Secretary of State for the Environment, the Secretary of State for Scotland and the Secretary of State for Wales. 27 October, 1970]

The Conservatives pawned the bases for the future welfare policy which would correspond to long-term needs of a succeeding and responsible society. In particular, they had made a record increase in national insurance pensions and major improvements in the position of armed forces and public service pensioners; they accepted the decision to give pensions to persons over 80; they made new help available to younger widows, as well as to the long term sick and disabled. At the Cabinet meeting the decision to increase the social benefits in 1971 and 1973 had been approved. In 1971 it was approved the increase in grants up to a level of the cost of living, plus 25 per cent of the difference between that and the increase in real earnings in industry. In 1973 it was planned a total uprating equivalent to the cost of living plus 60 per cent of the difference between that and the increase in real earnings in industry. At the same time these figures had been considerably cut down in comparison with the previous calculations. The economy in 1971/72 should make a profit of $£ 75$ million, and in 1974/75 - $£ 210$ million [Health, Welfare and Social Security. CONCLUSIONS of the Cabinet, 5 October, 1970].

Reorganization was mentioned also the public health services. On coming to power the Conservatives 'have asked citizens to pay more for medical perscriptions', that had allowed them 'to direct more money to repairing the old hospitals and improvement the standards of care for aged and mentally sick people' [Edward Heath, 1970]. The gradual increase in the cost of medical recipes by 25 per cent should bring additional income $£ 27$ million in 1971/72, and $£ 37$ million in 1974/75 [NEW POLICIES FOR PUBLIC EXPENDITURE: DRAFT WHITE PAPER. Note by the Chancellor of the Exchequer. 13 October 1970]. In public health services practically all categories of medical staff was actively encouraged to enter private practise. Under the Bill of 1973 doctors were given the right to use the medical equipment of public hospitals for service of private clients, the quantity of beds in public hospitals allocated for private patients was increased. This allowed not only for the stimulation of private business, but also considerably reduced queues in hospitals. At the same time, from 1 April, 1972, the payment for a stay in hospital was raised by 1 to 3 pounds [PRIVATE PRACTICE IN NATIONAL HEALTH SERVICE HOSPITALS: DRAFT WHITE PAPER. Memorandum by the Chancellor of the Exchequer. 21 March, 1973]

E. Heath paid great attention to the efficiency of Government decisions. The White Book published in October, 1970 emphasized the need for reorganization of structure and functions of the central government, reduction of departments and expenditure, improvement of the decision-making mechanism that should guarantee in future the ability of the governmental mechanism to adapt for a change of policy. In the Prime Minister's 
opinion, a great deal of governmental functions and duties overloaded the mechanism of management and became 'a severe burden for the industry and citizens of the country'. As a result, weak aspects of the governmental decision-making mechanism had arisen. They put a damaging effect on quality of many decisions taken by the Government. In this regard, Heath had asked each Minister to examine the expediency of every function carried out in his department as well as whether it was essential for each of these function to continue within the frameworks of the Government. Revision of functions was carried out according to the long-term strategy to free the private initiative and investment and put the greater responsibility to the individual and a lesser one to the State.

For the purpose of increase the government efficiency it was offered to develop various options for decisions to be taken by the Ministers in accordance with the national needs. So, the regular formulation of alternative options at a level of committees and below should create conditions for a greater openness of the government, its greater responsiveness for needs and wants of a society and individuals, i.e. it would promote the balance between the individual and the modern State [WHITE PAPER on the reorganization of central government. Note by the Prime Minister. 14 October 1970].

In order to simplify the Government, Ministries of Trade and Technologies had been incorporated within one department of Trade and Industry. The Ministries of Housing and Local Government, the State Building, the Enterprises and Transport have been incorporated in one department of the Environment with large responsibilities in the sphere of land cadastre, construction of the industrial enterprises (including housing programmes), and transport industry, protection of the environment and the control of pollution. [Machinery of Government. CONCLUSIONS of the Cabinet, 15 October, 1970].

To increase government efficiency parliamentary reform had been proposed. Its implementation allowed the House of Commons to approve many bills 'as due' and to avoid discussions on much debated issues. It was provided due to the system of special Committees (closely connected with governmental officials), which were coordinated by the official group of chairmen of the Committees. In particular, the Estimates Committee which had been founded in 1966 for check of the departments operation and reports on expenditures had been replaced with an Expenditure Committee with a limited number of members up to 45 (instead of 80) [Green Paper. Select Committees. Memorandum by the Lord President of the Council].

With the purpose to establish the new form of interrelations between the central and local authorities Local Government reform was also announced. The reform had been realised in different periods in Scotland, England and the Wales. It had been directed toward an increase of efficiency of local management and to reduction of central government control and establishment of the bases for greater independence of local authorities. It was entered the principle of equality in relations between the central and local authorities. According to it both authorities were considered as partners in relations with each other. Thus, the structure of local authorities should have a sufficient number of highly paid professionals and technical advisers to lower the degree of intervention in local affairs from central management. However, it did not mean full independence of local authorities. The central government preserved the right of control of financial activity, as well as some administrative and technical control.

One of the basic directions of neo-conservative policy was the foreign policy of the Great Britain directed on steady protection and promotion of interests of the country 
worldwide. With the purpose of strengthening of the country's authority on the international scene the government had approved the decision to continue rendering financial help to developing countries and to raise it by the 25 anniversary of the General Assembly of the United Nations in 1975 to the size of 1 per cent of GNP (in conformity with the obligations earlier taken on). Arguing before the government, the Minister on foreign development had declared: 'If we refuse the earlier taken obligations we shall have to declare our reservations. It will cause not only mistrust to the British economy, but also the even greater damage coursed by reduction of financial and commercial contracts in the world market. Moreover, it is in the interests of Britain as the most part of the developing world countries are the countries of the Commonwealth' [THE BRITISH CONTRIBUTION TO DEVELOPMENT. Memorandum by the Minister of Overseas Development. 22 September 1970]. Nevertheless, the analysis of the governmental expenditures made in July, 1973 testified that the Great Britain, despite of annual increase in the help on the average of 8.1 per cent, was not able to reach the object in view. In 1974-75 it had been allocated $£ 299.7$ million, and $£ 327.4$ million in $1975-76$ amounting to 0.4 per cent and 0.42 per cent of GNP respectively [PUBLIC EXPENDITURE TO 1977-78. Memorandum by the Chancellor of the Exchequer. 17 July, 1973]. In the sphere of defence, the Conservatives had continued to implement the decision taken by the Labour Government on the departure of armed forces from the areas East of Suez though the terms of a final departure had been considerably removed. Defence expenditures on the policy East of Suez should be reduced in the following sequence: in $1971-72$ by $£ 20$ million; in $1972-73$ by $£ 23$ million; in 1973-74 by $£ 64$ million; in 1974-75 by $£ 132$ million [Defence. CONCLUSIONS of the Cabinet, 29 September, 1970]. However, the total sum of military expenditures contin-

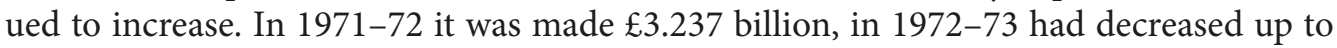
$£ 3.199$ billion, and in $1973-74$ had increased up to $£ 3.347$ billion [PUBLIC EXPENDITURE TO 1977-78. Memorandum by the Chancellor of the Exchequer. 17 July, 1973].

The government had successfully solved the problem of EEC entry. Thus, Britain had protected the interests of the Commonwealth, having kept for them preferences during the transition period. However, it had been compelled to enter the value-added tax (VAT) that was new to Britain. The Government had connected its entry with a policy of simplification of tax system. So, since autumn 1972, instead of the Employment Tax and the Purchase Tax there was entered the VAT at a general rate of 16 per cent, with a reduced rate of 5 per cent for, e.g. fuel and education. One VAT was equal equivalence to two cancelled taxes. As a result the prices for essential goods had increased in 1.75 times, and on a luxury goods such as furs, jewellry, cars, on industrial goods of long use it decreased by 30-50 per cent [Value-Added Tax. CONCLUSIONS of the Cabinet, 5 November, 1970]. The government regarded it as 'achievement to which we can be proud'.

Foreign policy successes had allowed E. Heath to ascertain with a quiet satisfaction that in 1971 there was a real change of position of the Great Britain in the world. 'Today for the first time for long time - Britain's voice is being heard in the world again, not as plaintive whisper in the corridors of power but as a voice that speaks what it knows and knows what is has learned from history! That is why Europe needs us... In the quiet revolution these things mark the first silent steps. They need to be big strides to keep pace with the way the world is moving, Heath claimed [Edward Heath, 1971].

However, in 1972 the situation in economy had become complicated and the government had been compelled to redirect its efforts to struggle against inflation. In November, 
1972 during tripartite negotiations of the government, employers and trade unions an agreement has been reached on three objectives: 1) the need for faster growth in national output and real incomes, 2) for an improvement in the position of the low paid, 3) for moderation in the rate of cost and price inflation. Nevertheless, as it had appeared, it was impossible to reach consent regarding the means of reaching of these objectives. As a result, the government had introduced a standstill to a rise of prices, dividends and wages until the development of the coordinated program of actions which should run for 90 days but with provision for an extension up to a further 60 days [INFLATION (temporary provisions) BILL. Note by the Secretary of the Cabinet. 2 November, 1972].

In January, 1973 a Bill providing creation of two agencies was tabled: the commissions under the prices and advice on wages. A three-year period of price control, wages, dividends and a rent was given to the government. In particular, there was a task in view to bring a level of wages into accord with a level of growth of manufacture (the increase in wages should not exceed 1 pound in a week, plus 4 per cent from average wages in branch, but no more than 250 per year); to limit growth of dividends by no more than 5 per cent from usually paid sum; to lower rent by 50 per cent and to increase grants to low-paid citizens by 2.50 [PRICES and PAY - THE NEXT PHASE was expected: draft White Paper. Note by the Chancellor of the Exchequer. 12 January, 1973]. Critics of Heath's politics had regarded these steps as 'the first and largest deviation from the principles of "a quiet revolution", as a harbinger as "a U-turn" [1972 MARCH 21: BUDGET].

Thus, 'a quiet revolution' had aimed to realise radical changes which concerned every aspect of daily life in British society. It incorporated basic principles such as individual independence and responsibility, self-reliance and thrift, freedom of business and reduction of state intervention. These and other primordially conservative values E. Heath's Government aspired to adapt to new conditions of the form of industrial society that demanded increase in manufacture of industrial goods and expansion of commodity markets.

However, the Government's freedom of action was hampered by a number of limitations, such as the high level of the State expenditure and taxation, the outmoded system of industrial relations which had interfered with the growth of the financial sector and industrial losses from strikes, stagnation of economy and growth of inflation. With the purpose of realisation of the proclaimed ideas, the government's task consisted in eliminating restrictions constraining its policy and providing a room for manoeuvre, not only for Heath's Government, but also for the would-be Government of M. Thatcher. But, while inside the country the Government had levers to control and manage the situation, on a world stage Great Britain's policy was under the influence of factors which were not under British control and rendered a negative influence. Their overcoming needed interaction with other countries within frameworks of integrated associations and international organizations in which British influence had increased. In sum, despite the constraints, the Government's policy promoted a quiet advancement of the epoch of neo-conservatism.

\section{References}

One Nation Conservatism and social policy, 1951-64. Available at: http://www. eprints.lincoln.ac.uk/2973/1/ One_Nation_100323.pdf (accessed 12.01.2017).

Edward Heath, 1967. Leader's speech. Speech Archive. Available at: http://www.britishpoliticalspeech.org/ speech-archive.htm?speech=114 (accessed 12.01.2017).

Edward Heath, 1968. Leader's speech. Speech Archive. Available at: http://www.britishpoliticalspeech.org/ speech-archive.htm?speech=115 (accessed 12.01.2017). 
Edward Heath, 1970. Leader's speech. Speech Archive. Available at: http://www.britishpoliticalspeech.org/ speech-archive.htm?speech=117 (accessed 10.12.2016).

Edward Heath, 1971. Leader's speech. Speech Archive. Available at: http://www.britishpoliticalspeech.org/ speech-archive.htm?speech=118 (accessed 10.12.2016).

Public Expenditure. CONCLUSIONS of the Cabinet held at 10 Downing Street, 14 September, 1970. CAB 128-147. Available at: http://www.nationalarchives.gov.uk (accessed 12.01.2017).

THE ECONOMIC OUTLOOK. Memorandum by the Prime Minister. 21 July 1970. CAB 129-150. Available at: http://www.nationalarchives.gov.uk (accessed 10.12.2016).

Public Expenditure. CONCLUSIONS of the Cabinet held at 10 Downing Street, 15 September, 1970. CAB 128-147. Available at: URL: http://www.nationalarchives.gov.uk (accessed 10.12.2016).

NEW POLICIES FOR PUBLIC EXPENDITURE: DRAFT WHITE PAPER. Note by the Chancellor of the Exchequer. 13 October 1970. CAB 129-153. Available at: http://www.nationalarchives.gov.uk (accessed10.12.2016).

CABINET. PUBLIC EXPENDITURE. Memorandum by the Chief Secretary, Treasury. 10 September 1970. CAB 129-151. Available at: http://www.nationalarchives.gov.uk (accessed 10.12.2016).

Economic Affairs. CONCLUSIONS of the Cabinet held at 10 Downing Street, 3 September, 1970. CAB 128-147. Available at: http://www.nationalarchives.gov.uk (accessed 10.12.2016).

Pay of the Higher Civil Service. CONCLUSIONS of the Cabinet held at 10 Downing Street, 21 July, 1970. CAB 128-147. Available at: http://www.nationalarchives.gov.uk (accessed 10.12.2016).

INDUSTRIAL RELATIONS SITUATION. Memorandum by the Secretary of State for Employment and Productivity. 1 July 1970. CAB 129-150. Available at: http://www.nationalarchives.gov.uk (accessed 10.12.2016).

INDUSTRIAL RELATIONS LEGISLATIN. Memorandum by the Secretary of State for Employment and Productivity. 28 July 1970. CAB 129-151 (39). Available at: http://www.nationalarchives.gov.uk (accessed 10.12.2016).

Public Expenditure. Education. CONCLUSIONS of the Cabinet held at 10 Downing Street, 5 October, 1970. CAB 128-147. Available at: http://www.nationalarchives.gov.uk (accessed 10.12.2016).

Housing Finance. CONCLUSIONS of the Cabinet held at 10 Downing Street, 30 October, 1970. CAB 128147. Available at: http://www.nationalarchives.gov.uk (accessed 10.12.2016).

Health, Welfare and Social Security. CONCLUSIONS of the Cabinet held at 10 Downing Street, 5 October, 1970. CAB 128-147. Available at: http://www.nationalarchives.gov.uk (accessed 10.12.2016).

WHITE PAPER on the reorganization of central government. Note by the Prime Minister. 14 October 1970. CAB 129-153. Available at: http://www.nationalarchives.gov.uk (accessed 10.12.2016).

Machinery of Government. CONCLUSIONS of the Cabinet held at 10 Downing Street, 15 October, 1970. CAB 128-147. Available at: http://www.nationalarchives.gov.uk (accessed 10.12.2016).

Green Paper. Select Committees. Memorandum by the Lord President of the Council. Available at: http:// www.nationalarchives.gov.uk (accessed 10.12.2016).

Public Expenditure. Defence. CONCLUSIONS of the Cabinet held at 10 Downing Street, 15 September, 1970. CAB 128-147. Available at: http://www.nationalarchives.gov.uk (accessed 10.12.2016).

Defence. CONCLUSIONS of the Cabinet held at 10 Downing Street, 29 September, 1970. CAB 128-147. Available at: http://www.nationalarchives.gov.uk (accessed 10.12.2016).

THE BRITISH CONTRIBUTION TO DEVELOPMENT. Memorandum by the Minister of Overseas Development. 22 September 1970. Available at: http://www.nationalarchives.gov.uk (accessed 10.12.2016).

Overseas Aid. CONCLUSIONS of the Cabinet held at 10 Downing Street, 5 October, 1970. CAB 128-147. Available at: http://www.nationalarchives.gov.uk (accessed 10.12.2016).

Value - Added Tax. CONCLUSIONS of the Cabinet held at 10 Downing Street, 2 November, 1970. CAB 128-147. Available at: http://www.nationalarchives.gov.uk (accessed 10.12.2016).

INFLATION (temporary provisions) BILL. Note by the Secretary of the Cabinet. Draft of a Bill. 2 November, 1972. CAB 129-165. Available at: http://www.nationalarchives.gov.uk (accessed 10.12.2016).

PRICES and PAY - THE NEXT PHASE: draft White Paper. Note by the Chancellor of the Exchequer. 12 January, 1973. CAB 129-167. Available at: http://www.nationalarchives.gov.uk (accessed 10.12.2016).

1972 MARCH 21: BUDGET. Available at: http: www. margaretthatcher.org/archive/heath.asp (accessed 10.12.2016).

Received: 01.03.2017

Accepted: 20.11.2017 